\title{
A Review on Recent Advancements in Roller Compacted Concrete
}

\author{
Veerendrakumar C Khed, Gokulanadh V, Hema Latha M
}

\begin{abstract}
Roller Compacted Concrete (RCC) is a durable material highly used for Pavements and Dams construction. In this regard being a high qualified material for its many advantages like Faster paving, Labor savings, Tax savings etc., researchers have produced many significant studies and derived the best results by various approaches. Some research includes the study of roller compacted concrete by partial replacement of cementitious minerals such as GGBS, admixtures like Glass fibres, Synthetic Fibres etc. With the help of locally available materials many tests have been conducted and results were shared to the world for further scope of study. Roller compacted concrete (RCC) has many advantages and the main attraction is its low water requirement with high workability and high compaction. This automatically results the outstanding compression strength. Current research has been focused on the improvement of mechanical properties and durability of the roller Compacted concrete incorporating different minerals and materials. In this paper, the Review of the papers have been presented in order to come to an overall understanding of the current progress for the Roller Compacted Concrete which is mainly being used for Roads, pavements, Parking lots and Dams.
\end{abstract}

Keywords: RCC, Compressive Strength, Pavements, Synthetic Fibres.

\section{INTRODUCTION}

$\mathrm{R}$ oller compacted concrete (RCC) is well known for its cost efficiency, low heat of hydration, and no-slump characteristics. These attributes make it suitable for large-scale construction projects such as gravity dams and Willow Creek Dam of America in 1982, RCC dams have developed rapidly. There are more than 550 RCC dams already built or under construction all over the word, and China alone accounts for 165 of them. Moreover, China owns the tallest RCC dam called Longtan Dam in Guangxi province whose height is $216.5 \mathrm{~m}$ [1]. As a widely used material in the construction of dams and airport pavements, layered roller compacted concrete (RCC) has been confirmed by Wang et al. [2] that the specimen size shows a great influence on various

Revised Manuscript Received on September 21, 2020.

*Correspondence Author

Veerendrakumar C Khed*, Assoiciate Professor, Department of Civil Engineering, Koneru Lakshmaiah Education Foundation, Vaddeswaram, Guntur District - 522502, Andhra Pradesh, India. Email: vchkhed@kluniversity.in

Gokulanadh V, Master of Technology in Structural Engineering, Department of Civil Engineering, Koneru Lakshmaiah Education Foundation, Vaddeswaram, Guntur District - 522502, Andhra Pradesh, India. Email: vagvalagokulanadh@gmail.com

Hema Latha M, Master of Technology in Structural Engineering, Department of Civil Engineering, Koneru Lakshmaiah Education Foundation, Vaddeswaram, Guntur District - 522502, Andhra Pradesh, India. Email: margani.hema127@gmail.com

(C) The Authors. Published by Blue Eyes Intelligence Engineering and Sciences Publication (BEIESP). This is an open access article under the CC BY-NC-ND license (http://creativecommons.org/licenses/by-nc-nd/4.0/) pavements. Since the construction of the first RCC dam, the

dynamic compressive behaviors of RCC. Compaction is the most important stage of construction: it provides density, strength, smoothness, and surface texture. Compaction begins immediately after placement and continues until the pavement meets density requirements. The main advantages are cost reduction, time of the total construction, Less spillway costs. Few disadvantages are grade of Fine aggregate and Coarse aggregate should be qualified, otherwise the strength may not be achieved as per expectations. In this current review paper, the recent advancements in the Roller Compacted concrete have been studied.

\section{COMPRESSIVE STRENGTH}

Compressive strength is used to satisfy design loading requirements ans also provides information for the other strength characteristics and properties. The Compressive strength tests are performed in accordance with the ASTM C39/C39M during al the phases for roller compacted concrete. Solomon et al., experimented on Reclaimed Asphalt Pavement (RAP) (50\% coarse \& fine RAP) by adding few industrial and agricultural wastes such as Silica Fume (SF), Fly Ash (FA) and Sugarcane Ash (SA) and have found that SF produced good results in case of Compressive Strength [3]. Rahmani et al., in his investigation on water cement ratio content in Roller compacted Concrete has concluded that the compressive strength was doubled when $\mathrm{W} / \mathrm{C}$ ratio increased from 0.3 to 0.55 [4]. Zeynep et al., experimented on macro-synthetic fibre reinforced Roller compacted concrete for Freeze-thaw resistance and water permeability. He found that the highest compressive strength obtained at $0.4 \%$ MS Fibre [5]. Davoud et al., has done the experimentation on roller compacted concrete and replaced sand with various waste materials also cement with $0.5 \%$, $0.7 \%, 1 \%$ and $1.5 \%$ Nano $\mathrm{SiO} 2$. He found that the Compressive Strength of mix C10CR and C10GL samples were equal to the Actual control mix. Furthermore , the compressive strength of other mixes that with waste Sand decreased relative to the control Mix [6]. Hashemi et al., studied the effects of using low fines content sand on the fresh and hardened properties of roller-compacted concrete. He concluded that by using the low fines, the compression strength has not shown much difference on the 1st day and 7th day compression test. However, on 28th day test, there was slight decrease of $3 \%$ in the compression strength. Altogether the LSP modified sand shown the lowest compressive strength compared with the standard sand and low fines [7]. Rooholamini et al., studied the fracture properties of the hybrid fibre reinforced roller compacted concrete and found that the Hybrid fibre reinforced roller compacted concrete proves to gives $8.2 \%$ more fracture thoughness compared to plain [8]. 
Linghua et al., studied on the mechanical properties and frost resistance of roller compacted concrete by mixing silica fume and limestone. He found the compressive strength, split tensile strength and elastic modulus of RCC with admixtures (i.e. $20 \%$ limestone powder $+20 \%$ fly ash (LF), $5 \%$ silica fume $+35 \%$ fly ash (SF), $20 \%$ limestone powder $+5 \%$ silica fume $+15 \%$ fly ash (LSF)) were determined from $7 d$ up to 90d. LSF has optimal mechanical performance on 7d and 28d. However in case of compression strength, LSF tops the results on $7 d$ and $28 d$ whereas on the $90 d$ testing, SF proves to show much improvement in the compressive strength [9]. Sengün et al., has done the experiment on Effects of compaction methods and mix paramenters on the properties of the roller compacted concrete. They found that the mechanical properties of RCC mixtures were highly affected by the compaction ratio, then by the cement content. Increase of water content resulted in the increase of mechanical properties. Water content if increased resulted in the increase of the strength of RCC mixes [10]. Sukontasukkul et al., has done Case investigation on application of steel fibers in roller compacted concrete pavement in Thailand. They found that water requirement increased with the presence of fibres. The compression load responses were similar for both FRCCP and RCCP during early age, whereas at 28d compressive strength of Fibre reinforced roller compacted concrete slightly decreased by 1-2\% [11]. Rooholamini et al., has done experiment to find the Effect of electric arc furnace steel slag on the mechanical and fracture properties of roller-compacted concrete. He has concluded that the compressive strtength was increased when coarse steel slag is used. When $50 \%$ of fine aggregate was used the compressive strength has been decreased [12]. Abbaszadeh et al., in his research, the durability and mechanical properties of roller compacted concrete designed for pavement containing different amounts of cement kiln dust as ordinary Portland cement replacement were evaluated before and after freeze-thaw cycles and found that replacing a part of cement with CKD reduced the compactibility of RCCP and stated that the optimum CKD content was equal to $2 \%$ by dry mass of aggregates [13]. AliAhmad et al., has done Probabilistic and experimental investigating the effect of pozzolan and Lumachelle fine aggregates on roller compacted concrete properties. He found that The RCC compressive strength was reduced by distancing from the percent optimum moisture due to improper compaction. Furthermore, he also stated the use of more than 20\% Pozzolan caused more strength reduction [14]. Sherong et al., done experiment on Compressive behavior and constitutive model for roller compacted concrete under impact loading by Considering vertical stratification. He stated that the dynamic mechanical properties of RCC, containing compressive strength, Young's modulus and critical strain at peak stress, increase with the increasing strain rates [15]. Mohsen et al., had done an Experimental investigation of using cross-linked polyethylene waste as aggregate in roller compacted concrete pavement. He found that the 28-d compressive strength of specimens containing 5\% of XLPE waste was more than the minimum compressive strength prescribed by the RCCP guide [16]. NgocTra et al., studied and experimented on Roller-compacted concrete pavement made of Electric Arc Furnace slag aggregate and its Mix design and mechanical properties. He found that by using EAF , compressive strength decreased. A predicting model for compressive strength of RCCP has been given ad the mean absolute percentage error of measured strength and calculated strength by the predicting model is less than $10 \%$ [17]. Jeff et al., done research on Mechanical properties of roller-compacted concrete with macro-fibers. They found that RCC mixes having synthetic fiber types had increase in MDD and compressive strength relative to the RCC control mixture [18]. Ahmed et al., done research on Production of roller-compacted concrete using glass powder. Concluded that the substitution of cement by GP improves compressive strength. The GP concrete produce good results as long as curing is done for the pozzolanic reaction of the GP [19]. Ghaharia et al., has studied on the Performance Assessment Of 1 Natural Pozzolan Roller Compacted Concrete Pavements. He found that mix R32 has given good results for the compressive strength compared to the control mix. The compressive strength of the specimens containing Trass is $35 \%$ lower than that of the plain concrete at early ages [20]. Mingchao $\mathrm{Li}$ et al., has done research on Mechanical properties investigation of high-fluidity impermeable and anti-cracking concrete in high roller-compacted concrete dams. He concluded that the compressive strength of HIAC in grade C25 given $37.89 \mathrm{MPa}$ and stated that the result is 1.52 times the design strength [21]. Chamroeun et al., done A study on performance of roller-compacted concrete for pavement. He concluded that The optimal Vebe time or consistency for compressive strength tends to be stiffer compared to those of compacted depth, IRI and skid resistance [22]. Kaarthik et al., experimented on enhancement of properties of concrete using natural fibres. He added coconut coir and sisal fibre to the concrete and various experiments have been performed and the results for compressive strength, deflection and axial load carrying capacity are reported. He found that the increase in ductility and strength of concrete was achieved for the addition of coir of $1.5 \%$ the weight of cement which was found to be the optimum percentage [23]. Chamroeun et al., investigated on relationship between compressive, flexure and tensile strength of roller compacted and conventional concrete. He concluded that the effect of compaction on the RCC is significant as the aggregate interlock can be improved, thereby increasing the early and overall compressive strengths [24]. Chao et al., investigated on how the aggregate size influence the compressive strength of roller compacted concrete and concluded that the compressive strength decreases with the increasing the aggregate size [25]. Hashemi et al., experimented on how the coarse to fine aggregate ratio influence the hardened properties of the roller compacted concrete and concluded that the the compressive, splitting tensile and flexural strengths increased significantly as the $\mathrm{C} / \mathrm{F}$ ratio increased from 1.2 to 1.4 and also concluded that the $\mathrm{C} / \mathrm{F}$ ratio in between 1.2 and 1.4 is optimum for RCC mixture [26]. 
NgocTra et al., a investigated on properties of roller-compacted concrete pavement containing electric arc furnace slag aggregate and flyash and concluded that the Compressive strength of group A (with natural aggregate) is higher than that of group B (with 50\% EAF slag coarse aggregate) and group C (with 100\% EAF slag coarse aggregate). Bashar et al., investigated the mechanical performance of roller compacted concrete pavement containing crumb rubber and nano silica and concluded that the compressive strength of roller compacted concrete decreases with replacing fine aggregate with CR above10\% [27]. Bashar et al., investigated the effect of Crumb rubber and Nano silica on the properties of High volume fly Ash Roller compacted concrete pavement using Non-destructive Techniques and concluded that the incorporation of crumb rubber as a partial replacement to fine aggregate in HVFA RCC pavement leads to decrease in unit weight and compressive strength and nano silica increases the unit weight, compressive strength [28]. Musa et al., experimented on performance of high volume fly ash roller compacted concrete containing crumb rubber and nano silica and concluded that the compressive strength of HVFA RCC pavement decreased with increasing crumb rubber content as replacement of fine aggregate and also concluded that the addition of nano-silica increases the compressive strength of HVFA RCC pavement [29].

From the above papers we can conclude that Roller compacted concrete has been a boon in case of Compressive strength as it naturally increased $45 \%$ compared to the normal concrete due to high compaction. Furthermore the primary reason behind the incorporation of fibers into cement matrix is to increase the toughness, tensile strength and improving the cracking deformation characteristics [30]. Also that the addition of glass and jute fibers increases $19 \%$ to traditional mix of its strength [31]. Some additional admixtures like the Sugarcane Bagasse Ash can be utilized for partial replacement of cement up to $15 \%$ by weight of cement without any major loss of strength[32]. Compressive strength, split tensile strength and flexural strength of green concrete tend to vary in direct relation to percentage of GGBS slag content. The strength variation for Compressive strength is $33.5 \%$, split tensile is $30.9 \%$, flexural strength is $25.7 \%$ [33]. Bentonite which is research attraction used as replacement for OPC increase the compressive strength for the plain concrete. If added $20 \%$ it improves mechanical properties and further it has good workability [34]. All these serve to improve the mechanical properties and further research can be done. As per the above observations the addition of Silica fume has shown good results in terms of compressive strength. In case of any fibre addition, compression strength is decreasing. So in order to overcome such problem, additional materials are being used for the Roller Compacted Concrete.

\section{FLEXURAL STRENGTH}

Flexural strength, known as modulus of rupture, or bend strength, or transverse rupture strength is a material property, defined as the stress in a material just before it yields in a flexure test. The flexural strength represents the highest stress experienced within the material at its moment of yield. It is measured in terms of stress, here given Sigma. Solomon et al., experimented on Reclaimed Asphalt Pavement (RAP) (50\% coarse \& fine RAP) by adding few industrial and agricultural wastes such as Silica Fume (SF), Fly Ash (FA) and Sugarcane Ash (SA) and have found that only SF produced good results in case of Rupture [3]. Rahmani et al., in his investigation on water cement ratio content in Roller compacted Concrete has concluded that the Modulus of Rupture decreases upto 35\% when W/C ratio increased from 0.3 to 0.55 and also that with the increase of C/A from $12 \%$ to $17 \%$ rupture increased upto $40 \%$ [4]. Zeynep et al., experimented on macro-synthetic fibre reinforced Roller compacted concrete for Freeze-thaw resistance and water permeability. He found that the highest flexural strength obtained at $0.4 \%$ MS Fibre [5]. Hashemi et al., studied the effects of using low fines content sand on the fresh and hardened properties of roller-compacted concrete. He concluded that by using the low fines, the LSP modified sand shown the lowest flexural strength compared with the standard sand and low fines [7]. Sukontasukkul et al., has done Case investigation on application of steel fibers in roller compacted concrete pavement in Thailand. They found that water requirement increased with the presence of fibres. The flexural strength of the FRCCP proved to be better compared to the conventional RCCP. It was observed to increase $10-20 \%$ of the flexural strength. Similarly toughness and residual strength increased. At the 28d there was an increase of residual strength of $67-82 \%$ for $0.5 \%$ FRCCP and $1.0 \%$ FRCCP [11]. Abbaszadeh et al., in his research, the durability and mechanical properties of roller compacted concrete designed for pavement containing different amounts of cement kiln dust as ordinary Portland cement replacement were evaluated before and after freeze-thaw cycles and found that replacing a part of cement with CKD reduced the compactibility of RCCP and stated that the optimum CKD content was equal to $2 \%$ by dry mass of aggregates. For Flexural Strength $2 \%$ CKD was found to produce good early strength results [13]. Shamsaei et al., had done an Experimental investigation of using cross-linked polyethylene waste as aggregate in roller compacted concrete pavement. He concluded that when XLPE replaced 5\% of the coarse aggregate, the 7 -d flexural strength increased by $6 \%$; however, the 14-d and the 28-d flexural strengths decreased slightly [16]. Jeff et al., done research on Mechanical properties of roller-compacted concrete with macro-fibers. They found that Flexural toughness and residual strengths for RCC mixes with fibers, increased with higher fiber content. Also, the hooked-end steel fiber had greater flexural toughness and residual strength comapred to the synthetic fibers in RCC [18]. Ahmed et al., done research on Production of roller-compacted concrete using glass powder. Concluded that the substitution of cement by GP improves flexural strength [19]. Ghaharia et al., has studied on the Performance Assessment Of 1 Natural Pozzolan Roller Compacted Concrete Pavements. He found that mix R32 has given good results for the compressive strength compared to the control mix.

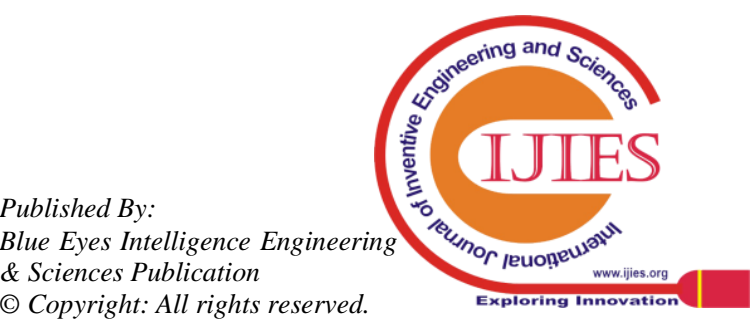




\section{A Review on Recent Advancements in Roller Compacted Concrete}

The flexural strength of the specimens containing Trass is $12 \%$ lower than that of the plain concrete at early ages [20]. Chamroeun et al., investigated on relationship between compressive, flexure and tensile strength of roller compacted and conventional concrete. He found that the aggregate interlock, along with the compressive strength helps in improving the strength of a flexural structure [24]. Hashemi et al., experimented on how the coarse to fine aggregate ratio influence the hardened properties of the roller compacted concrete and concluded that the the compressive, splitting tensile and flexural strengths increased significantly as the $\mathrm{C} / \mathrm{F}$ ratio increased from 1.2 to 1.4 and also concluded that the $\mathrm{C} / \mathrm{F}$ ratio in between 1.2 and 1.4 is optimum for RCC mixture [26]. Rooholamini et al., evaluated the effect of macro-synthetic fibre on the mechanical properties of roller-compacted concrete pavement using response surface methodology and concluded that the Three-point bending test results showed that Macro-synthetic fibre has a very promising potential in improving flexural strength [35]. Bashar et al., investigated the mechanical performance of roller compacted concrete pavement containing crumb rubber and nano silica and concluded that the flexural strength increases with replacing fine aggregate with crumb rubber up to the $20 \%$ [27]. Musa et al., experimented on performance of high volume fly ash roller compacted concrete containing crumb rubber and nano silica and concluded that the flexural strength of HVFA RCC pavement decreased with increasing crumb rubber content as replacement of fine aggregate and also concluded that the addition of nano-silica increases the flexural strength of HVFA RCC pavement [29].

India has large amount of fly ash in generation all over the world. If this material is used properly many problems may be solved by the replacement fly ash . Flexural strength of concrete decreases with increase of fly ash [36]. In general, the addition of fibers gives a lower workability of fresh concrete composite. In case of coir fiber reinforced Concrete, the workability reduces to much extent. Scopes for further research may include full-scale flexural test, combination of natural and steel fibers, and use of supplementary cementitious materials to reduce Portland cement alkalinity in natural fiber concrete composite. It was finally concluded that tensile and flexural strength was increasing with increasing the volume of natural fiber content [30]. The tensile strength of the concrete mix was increased over a period with a higher amount of supplementary cementitious materials (FA, GGBS) and the addition of glass fiber [37]. Flexural Strength improved for the roller compacted concrete with the admixtures. Plain roller compacted concrete does not prove to be better in flexure. Hence it is highly advisable to incorporate any admixtures and cementitious materials for the improvement of flexural strength. Lingala et.al., has found that Alkali Resistant Glass fibres improved the Flexural properties [38]. These Glass fibres proved to come very handy for the improvement of Flexural properties. In one study about self compacting concrete with hybrid fibre reinforced rubberized cementitious composite HFRRCC it is found that crumb rubber partial replacement with fine aggregate weakens the flexural Strength. Whereas PVA fibre proved to give improvement in flexural strength. Similarly Tirewire also given positive result incase of flexural strength [39].

\section{SPLIT TENSILE STRENGTH}

Tensile strength is one of the basic and important properties of concrete. A knowledge of its value is required for the design of concrete structural elements. Its value is also used in the design of prestressed concrete structures, liquid retaining structures, roadways and runway slabs. Direct tensile strength of concrete is difficult to determine. A method of determining the tensile strength of concrete using a cylinder which splits across the vertical diameter. It is an indirect method of testing tensile strength of concrete.

Solomon et al., experimented on Reclaimed Asphalt Pavement (RAP) (50\% coarse \& fine RAP) by adding few industrial and agricultural wastes such as Silica Fume (SF), Fly Ash (FA) and Sugarcane Ash (SA) and have found that only SF produced good results in case of Split Tensile Strength [3]. Rahmani et al., in his investigation on water cement ratio content in Roller compacted Concrete has concluded that the Modulus of Split Tensile Strength decreased by $40 \%$ when $\mathrm{W} / \mathrm{C}$ ratio increased from 0.3 to 0.55 and also that with the increase of C/A from $12 \%$ to $17 \%$ Tensile strength increased upto 35\%. Mohammad Hashemi et al.,2019a studied the effects of using low fines content sand on the fresh and hardened properties of roller-compacted concrete. He concluded that by using the low fines, the LSP modified sand shown the less split tensile strength compared with the standard sand and low fines [4]. Linghua et al., studied on the mechanical properties and frost resistance of roller compacted concrete by mixing silica fume and limestone. He found the compressive strength, split tensile strength and elastic modulus of RCC with admixtures (i.e. $20 \%$ limestone powder $+20 \%$ fly ash (LF), 5\% silica fume $+35 \%$ fly ash (SF), $20 \%$ limestone powder $+5 \%$ silica fume $+15 \%$ fly ash (LSF)) were determined from $7 d$ up to 90d. LSF has optimal mechanical performance on $7 \mathrm{~d}$ and 28d. However in case of split tensile strength, LSF tops the results on $7 d$ and $28 d$ whereas on the $90 d$ testing, SF proves to top the results [9]. Rooholamini et al., a has done experiment to find the Effect of electric arc furnace steel slag on the mechanical and fracture properties of roller-compacted concrete. He has concluded that the Split tensile strength of mixes containing coarse steel slag aggregate was higher compared with the control mix. That contains fine EAF steel slag which was related to the variation in the contact surface of the aggregate-paste is rough for the cement paste [12]. Kaarthik et al., experimented on enhancement of properties of concrete using natural fibres. He added coconut coir and sisal fibre to the concrete and various experiments have been performed and the results for compressive strength, deflection and axial load carrying capacity are reported. He found that coir fiber delays and controls the tensile cracking of composite materials and it also enhances the ductility and energy absorption capacity [23]. Chamroeun et al., investigated on relationship between compressive, flexure and tensile strength of roller compacted and conventional concrete. 
He found that the splitting tensile strength of the RCC was found to be lower than that of the conventional concrete [24]. Hashemi et al., experimented on how the coarse to fine aggregate ratio influence the hardened properties of the roller compacted concrete and concluded that the the compressive, splitting tensile and flexural strengths increased significantly as the $\mathrm{C} / \mathrm{F}$ ratio increased from 1.2 to 1.4 and also concluded that the $\mathrm{C} / \mathrm{F}$ ratio in between 1.2 and 1.4 is optimum for RCC mixture [26]. Musa et al., experimented on performance of high volume fly ash RCC containing crumb rubber and nano silica and concluded that the splitting tensile strength of HVFA RCC pavement decreased with increasing crumb rubber content as replacement of fine aggregate and also concluded that the addition of nano-silica increases the split tensile strength of HVFA RCC pavement [29].Bashar et al., investigated the mechanical performance of RCC pavement containing crumb rubber and nano silica and concluded that the split tensile strength of roller compacted concrete decreases with replacement of FA with CR above10\% [27]. Abbaszadeh et al., in his research, the durability and mechanical properties of roller compacted concrete designed for pavement containing different amounts of cement kiln dust as ordinary Portland cement replacement were evaluated before and after freeze-thaw cycles and found that replacing a part of cement with CKD reduced the compactibility of RCCP and stated that the optimum CKD content was equal to $2 \%$ by dry mass of aggregates. For indirect tensile Strength $2 \%$ CKD was found to produce good results [13]. Shamsaei et al., had done an Experimental investigation of using cross-linked polyethylene waste as aggregate in roller compacted concrete pavement. He said that when waste XLPE replaced coarse aggregate by $5 \%$, the $7-d, 14-d$ and 28-d splitting tensile strengths compared to the control specimens increased by $18 \%, 9 \%$ and $10 \%$, respectively [16]. NgocTra et al., studied and experimented on RCC pavement made of Electric Arc Furnace slag aggregate and its Mix design and mechanical properties. He found that EAF decreased the Split Tensile Strength . Therefore, it was recommended that the mixture containing EAF slag aggregate and $20 \%$ fly ash is the best for recycling a large amount of waste materials [17]. Jeff et al.,done research on Mechanical properties of roller-compacted concrete with macro-fibers. They found that the split tensile strength of the steel fibers increased the RCC control strength greater than synthetic fibers [18]. Mingchao et al., has done research on Mechanical properties investigation of high-fluidity impermeable and anti-cracking concrete in high roller-compacted concrete dams. He concluded that Silica Fume proved to improve Split tensile for Roller Compacted concrete. HIAC gives good results for the splitting tensile strength for normal concrete [21]. Split Tensile strength increases with the addition of admixtures can be clearly observed. Many admixtures and Silica Fume too played a major role in the improvement of Split Tensile Strength in many cases. Its an desired quality needed to be improved by the roller compacted concrete as it does not contain reinforcement.

\section{DURABILITY}

RCC, like conventional mass concrete, is prone to deterioration due to the effects of abrasion, freezing and thawing, and other factors such as alkali-aggregate reaction and sulfate attack. Solomon et al., experimented on
Reclaimed Asphalt Pavement (RAP) (50\% coarse \& fine RAP) by adding few industrial and agricultural wastes such as Silica Fume (SF), Fly Ash (FA) and Sugarcane Ash (SA) and have found that SF produced good results in case of Durability [3]. Zeynep et al., experimented on macro-synthetic fibre reinforced Roller compacted concrete for Freeze-thaw resistance and water permeability. He found that the MS Fibres increased the durability by $60 \%$ than the normal [5]. Mohammadi et al., done research on Durability properties of non-air entrained RCC pavement having coal waste ash in presence of de-icing salts. He concluded that the C0, C2 and C3 mixes showed same behavior. The UPV and durability factor of C4 mix showed a reduction after 180 freeze-thaw cycles. This mix has critical durability properties in the presence of de-icing salts[40]. Ahmed et al., done research on Production of roller-compacted concrete using glass powder. The GP inclusion in the RCC induces a positive impact on durability properties [19]. Naveena et al., experimented fibre reinforced bream column joint by partial replacement of cement by GGBS. She concluded that the corrosion resistance of the fiber concrete increases with $30 \%$ of GGBS where by increasing in GGBS content, the compressive strengths decreases to $40 \%$ in acid attack [41]. Muralidhar et al., experimented on Strength and durability properties of light weight fibre reinforced concrete. They found that M3 mix containing fibre and more GGBS shown good results [42]. Davoud et al., has done the experimentation on roller compacted concrete and replaced sand with various waste materials also cement with $0.5 \%$, $0.7 \%, 1 \%$ and $1.5 \%$ Nano SiO2 . He found that the samples containing $10 \%$ glass and $10 \%$ ceramic wastes showed reduction in abrasion. The other samples showed increase of abrasion relative to Control mix. On the other hand samples containing $\mathrm{SiO} 2$, abrasion has been decreased due to the formation of microstructure of cement paste [6]. NgocTra et al., investigated on properties of roller-compacted concrete pavement containing electric arc furnace slag aggregate and flyash and concluded that the natural aggregate replaced by the EAF slag leads to increase the abrasion resistance of RCCP. This may be due to rough-surface texture of slag [43]. Bashar et al., investigated the mechanical performance of roller compacted concrete pavement containing crumb rubber and nano silica and concluded that the abrasion resistance of RCC increases with incorporation of $10 \%$ CR as replacement to fine aggregate and addition of up to $3 \%$ NS by weight of cementitious materials [27]. Musa et al., experimented on performance of high volume fly ash roller compacted concrete containing crumb rubber and nano silica and concluded that the abrasion resistance of HVFA RCC pavement decreased with increasing crumb rubber content as replacement of fine aggregate and also concluded that the addition of nano-silica increases the abrasion resistance of HVFA RCC pavement [29].

Durability tests is a reliable information in case of pavements, since it does not have reinforcement and the acid attack tests will eventually reveal its suitability in the field of construction. As per current study, Flyash has contributed good results incase of Durability. Some other admixtures like Glass powder and Silica Fume can also be incorporated for its improvement of Durability.

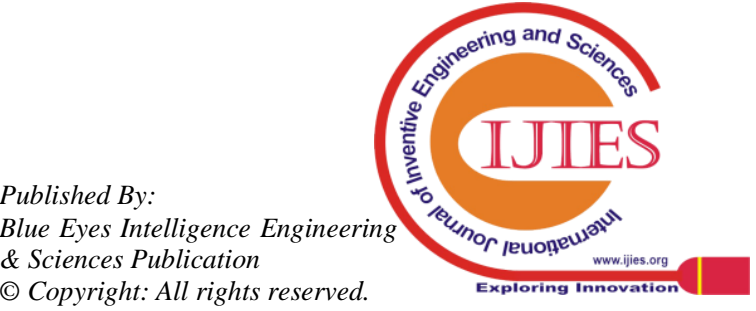




\section{A Review on Recent Advancements in Roller Compacted Concrete}

\section{SHRINKAGE}

Drying shrinkage is defined as the contracting of a hardened concrete mixture due to the loss of capillary water. This shrinkage causes an increase in tensile stress, which may lead to cracking, internal warping, and external deflection, before the concrete is subjected to any kind of loading. Sorabh et al., has experimented on effect of GGBS content and aggregate characteristics on drying shrinkage of roller compacted concrete . They found that RCC mixes has 50\% lesser shrinkage compared to that of conventional concrete due to lesser cement and water. RCC with crushed gravel has $23 \%$ higher shrinkage strain than the RCC with limestone. Also, increase in replacement of Cement with GGBS increases the shrinkage strain in both type of aggregates. Least shrinkage strain has been observed in 20\% replacement of GGBS with limestone aggregate [44]. Shrinkage is reduced with the replacement of cement material, GGBS in the above case. If water is reduced shrinkage is adversely reduced. In roller compacted concrete shrinkage is lesser compared to that of conventional concrete.

\section{SKID RESISTANCE}

In many cases accidents occur due to skidding of tires . This is a desired property incase of roads or pavements. Davoud et al., has done the experimentation on roller compacted concrete and replaced sand with various waste materials also cement with $0.5 \%, 0.7 \%, 1 \%$ and $1.5 \%$ Nano $\mathrm{SiO} 2$. He found that the increase in the waste materials increased the Skid resistance. However, Nano SiO2 along with wastes has lead to decreased skid resistance [6]. As per the research that the optimum levels of waste products needed to incorporated as it may reduce the skid resistance. NanoSiO2 should be used very less in order to achieve more durability.

\section{FREEZE THAW}

Freeze-thaw damage is a potentially serious deterioration process that occurs in concrete structures in cold climates. Zeynep et al., experimented on macro-synthetic fibre reinforced Roller compacted concrete for Freeze-thaw resistance and water permeability. He found that the MS Fibres incorporation has given satisfactory results for freeze thaw cycles [5]. Abbaszadeh et al., in his research, the durability and mechanical properties of roller compacted concrete designed for pavement containing different amounts of cement kiln dust as ordinary Portland cement replacement were evaluated before and after freeze-thaw cycles and found that replacing a part of cement with CKD reduced the compactibility of RCCP and stated that the optimum CKD content was equal to $2 \%$ by dry mass of aggregates [13]. Mohammadi et al., done research on Durability properties of non-air entrained RCC pavement containing coal waste ash in presence of de-icing salts. He concluded c4 did not produce good freezing condition results [40]. Wuman et al., investigated on the frost resistance of roller compacted concrete mixed with rubber particles and steel fibers and concluded that the total porosity of all specimens increases with the increase of freeze-thaw cycles and also concluded that the addition of rubber particles can obviously reduce the total porosity of specimens with and without freeze-thaw cycles [45]. Linghua et al., studied on the mechanical properties and frost resistance of roller compacted concrete by mixing silica fume and limestone. He found the compressive strength, split tensile strength and elastic modulus of RCC with admixtures (i.e. $20 \%$ limestone powder $+20 \%$ fly ash (LF), $5 \%$ silica fume $+35 \%$ fly ash (SF), $20 \%$ limestone powder $+5 \%$ silica fume $+15 \%$ fly ash (LSF)) were determined from $7 \mathrm{~d}$ up to $90 \mathrm{~d}$. LSF has optimal mechanical performance on $7 \mathrm{~d}$ and $28 \mathrm{~d}$. In case of frost resistance, SF proves to show worst frost resistance, whereas fly ash is detrimental for frost resistance. Addition of Limestone powder and silica fume are favourable for frost resistance. LSF is the best for frost resistance [9]. According to the findings above Fibres can play a major role in case of Free thaw cycles. It is indirectly related to water permeability and also Durability property to some extent. Mixing of additional waste materials and fibres give good freeze thaw resistance. Silica fume is to be avoided for good frost resistance.

\section{WATER ABSORPTION}

Absorption testing is a popular method of determining the water-tightness of concrete. NgocTra et al., investigated on properties of roller-compacted concrete pavement containing EAF slag and fly ash and concluded that the natural aggregate replaced by EAF slag leads to increase the water absorption of RCCP. This is due to high water absorption of slag [43]. Basharo et al., investigated the mechanical performance of roller compacted concrete pavement containing crumb rubber with nano silica and concluded that the water absorption increases with increment in CR and decreases with NS addition [29]. Less the water absorption more good the results are for the Water Absorption Test. It comes under Durability.

\section{CONCLUSION}

1) The above papers concluded that the effect of compaction on the RCC is significant as the aggregate interlock and be improved, thereby increases the compressive and flexure strengths and also concluded that the compressive strength mainly depends upon the aggregate size that is compressive strength of RCC decreases with the increasing aggregate size. If coconut coir and sisal fiber are used in RCC pavement an increase in the ductility and strength of concrete was achieved for the addition of coir of $1.5 \%$ the weight of cement which was found to be the optimum percentage.

2) The flexural strength of of high volume fly ash RCC pavement decreased with increasing crumb rubber content as replacement of fine aggregate and also concluded that the addition of nano-silica increases the flexural strength.

3) The split tensile strength of the RCC was found to be lower than the conventional concrete and the addition of nano-silica increases the split tensile strength of RCC pavement. If coconut coir is used in RCC pavement it controls the tensile cracks and it also enhances the ductility.

4) The glass powder inclusion in the RCC induces a positive impact on durability properties. 
5) The abrasion resistance of RCC increases with incorporation of $10 \%$ crumb rubber as replacement to fine aggregate and addition of up to $3 \%$ nano silica by the weight of cementitious material.

6) RCC mixes has $50 \%$ lesser shrinkage compared to that of conventional concrete due to lesser cement and water. RCC with crushed gravel has 23\% higher shrinkage strain than the RCC with limestone.

7) If sand is replaced with the waste materials and cement is replaced with $0.5 \%, 0.7 \%, 1 \%$ and $1.5 \%$ Nano $\mathrm{SiO} 2$, waste materials increases the Skid resistance. However, Nano SiO2 along with wastes has lead to decreased skid resistance.

8) Roller-compacted concrete pavement containing EAF slag and flyash, if the natural aggregate replaced by EAF slag leads to increase the water absorption of RCCP. This may be due to high water absorption of slag.

\section{REFERENCES}

1. G. Liu, W. Lu, Y. Lou, W. Pan, and Z. Wang, "Interlayer shear strength of Roller compacted concrete (RCC) with various interlayer treatments," Construction and Building Materials, vol. 166, pp. 647-656, 2018/03/30/ 2018

2. X.-h. Wang, S.-r. Zhang, C. Wang, R. Song, C. Shang, and X. Fang, "Experimental investigation of the size effect of layered roller compacted concrete (RCC) under high-strain-rate loading," Construction and Building Materials, vol. 165, pp. 45-57, 2018/03/20/ 2018.

3. S. Debbarma, G. D. Ransinchung R.N, S. Singh, and S. K. Sahdeo, "Utilization of industrial and agricultural wastes for productions of sustainable roller compacted concrete pavement mixes containing reclaimed asphalt pavement aggregates," Resources, Conservation and Recycling, vol. 152, p. 104504, 2020/01/01/ 2020

4. E. Rahmani, M. K. Sharbatdar, and M. H.A. Beygi, "The effect of water-to-cement ratio on the fracture behaviors and ductility of Rolle Compacted Concrete Pavement (RCCP)," Theoretical and Applied Fracture Mechanics, vol. 109, p. 102753, 2020/10/01/ 2020.

5. Z. Algin and S. Gerginci, "Freeze-thaw resistance and water permeability properties of roller compacted concrete produced with macro synthetic fibre," Construction and Building Materials, vol. 234, p. 117382, 2020/02/20/ 2020.

6. D. Tavakoli, R. Sakenian Dehkordi, H. Divandari, and J. de Brito "Properties of roller-compacted concrete pavement containing waste aggregates and nano SiO2," Construction and Building Materials, vol. 249, p. $118747,2020 / 07 / 20 / 2020$

7. M. Hashemi, P. Shafigh, M. Abbasi, and I. Asadi, "The effect of using low fines content sand on the fresh and hardened properties of roller-compacted concrete pavement," Case Studies in Construction Materials, vol. 11, p. e00230, 2019/12/01/ 2019.

8. H. Rooholamini, A. Hassani, and M. R. M. Aliha, "Fracture properties of hybrid fibre-reinforced roller-compacted concrete in mode I with consideration of possible kinked crack," Construction and Building Materials, vol. 187, pp. 248-256, 2018/10/30/ 2018.

9. L. Shen, Q. Li, W. Ge, and S. Xu, "The mechanical property and frost resistance of roller compacted concrete by mixing silica fume and limestone powder: Experimental study," Construction and Building Materials, vol. 239, p. 117882, 2020/04/10/ 2020.

10. E. Şengün, B. Alam, R. Shabani, and I. O. Yaman, "The effects of compaction methods and mix parameters on the properties of roller compacted concrete mixtures," Construction and Building Materials, vol. 228, p. 116807, 2019/12/20/ 2019.

11. P. Sukontasukkul, U. Chaisakulkiet, P. Jamsawang, S. Horpibulsuk, C. Jaturapitakkul, and P. Chindaprasirt, "Case investigation on application of steel fibers in roller compacted concrete pavement in Thailand," Case Studies in Construction Materials, vol. 11, p. e00271, 2019/12/01/ 2019.

12. H. Rooholamini, R. Sedghi, B. Ghobadipour, and M. Adresi, "Effect of electric arc furnace steel slag on the mechanical and fracture properties of roller-compacted concrete," Construction and Building Materials, vol. 211, pp. 88-98, 2019/06/30/ 2019.

13. R. Abbaszadeh and A. Modarres, "Freeze-thaw durability of non-air-entrained roller compacted concrete designed for pavement containing cement kiln dust," Cold Regions Science and Technology, vol. 141, pp. 16-27, 2017/09/01/ 2017.
14. M. AliAhmad, M. Miri, and M. Rashki, "Probabilistic and experimental investigating the effect of pozzolan and Lumachelle fine aggregates on roller compacted concrete properties," Construction and Building Materials, vol. 151, pp. 755-766, 2017/10/01/ 2017.

15. S.-r. Zhang, X.-h. Wang, C. Wang, R. Song, and H.-y. Huo, "Compressive behavior and constitutive model for roller compacted concrete under impact loading: Considering vertical stratification," Construction and Building Materials, vol. 151, pp. 428-440, 2017/10/01/ 2017

16. M. Shamsaei, I. Aghayan, and K. A. Kazemi, "Experimental investigation of using cross-linked polyethylene waste as aggregate in roller compacted concrete pavement," Journal of Cleaner Production, vol. 165, pp. 290-297, 2017/11/01/ 2017.

17. M. N.-T. Lam, S. Jaritngam, and D.-H. Le, "Roller-compacted concrete pavement made of Electric Arc Furnace slag aggregate: Mix design and mechanical properties," Construction and Building Materials, vol. 154, pp. 482-495, 2017/11/15/ 2017

18. J. LaHucik, S. Dahal, J. Roesler, and A. N. Amirkhanian, "Mechanical properties of roller-compacted concrete with macro-fibers," Construction and Building Materials, vol. 135, pp. 440-446, 2017/03/15/ 2017

19. A. Omran, D. Harbec, A. Tagnit-Hamou, and R. Gagne, "Production of roller-compacted concrete using glass powder: Field study," Construction and Building Materials, vol. 133, pp. 450-458, 2017/02/15/ 2017

20. S. A. Ghahari, A. Mohammadi, and A. A. Ramezanianpour, "Performance assessment of natural pozzolan roller compacted concrete pavements," Case Studies in Construction Materials, vol. 7 pp. 82-90, 2017/12/01/ 2017.

21. M. Li, M. Zhang, Y. Hu, and J. Zhang, "Mechanical properties investigation of high-fluidity impermeable and anti-cracking concrete in high roller-compacted concrete dams," Construction and Building Materials, vol. 156, pp. 861-870, 2017/12/15/ 2017

22. C. Chhorn, S. J. Hong, and S.-W. Lee, "A study on performance of roller-compacted concrete for pavement," Construction and Building Materials, vol. 153, pp. 535-543, 2017/10/30/ 2017.

23. N. K. Krishna, M. Prasanth, R. Gowtham, S. Karthic, and K. M. Mini, "Enhancement of properties of concrete using natural fibers," Materials Today: Proceedings, vol. 5, no. 11, Part 3, pp. 23816-23823, 2018/01/01/ 2018

24. C. Chhorn, S. J. Hong, and S. W. Lee, "Relationship between compressive and tensile strengths of roller-compacted concrete," Journal of Traffic and Transportation Engineering (English Edition), vol. 5, no. 3, pp. 215-223, 2018/06/01/ 2018.

25. C. Wang, W. Chen, H. Hao, S. Zhang, R. Song, and X. Wang, "Experimental investigations of dynamic compressive properties of roller compacted concrete (RCC)," Construction and Building Materials, vol. 168, pp. 671-682, 2018/04/20/ 2018

26. M. Hashemi, P. Shafigh, M. R. B. Karim, and C. D. Atis, "The effect of coarse to fine aggregate ratio on the fresh and hardened properties of roller-compacted concrete pavement," Construction and Building Materials, vol. 169, pp. 553-566, 2018/04/30/ 2018.

27. B. S. Mohammed and M. Adamu, "Mechanical performance of roller compacted concrete pavement containing crumb rubber and nano silica," Construction and Building Materials, vol. 159, pp. 234-251, 2018/01/20/ 2018

28. B. S. Mohammed, M. Adamu, and M. S. Liew, "Evaluating the effect of crumb rubber and nano silica on the properties of high volume fly ash roller compacted concrete pavement using non-destructive techniques," Case Studies in Construction Materials, vol. 8, pp. 380-391, 2018/06/01/ 2018.

29. M. Adamu, B. S. Mohammed, and M. Shahir Liew, "Mechanical properties and performance of high volume fly ash roller compacted concrete containing crumb rubber and nano silica," Construction and Building Materials, vol. 171, pp. 521-538, 2018/05/20/ 2018.

30. M. K. Velagala, G. Buddi, K. B. Chari, and I. S. J. T. Kishore, "TENSILE AND FLEXURAL BEHAVIOUR OF HIGH STRENGTH CONCRETE REINFORCED WITH NATURAL (VALVET MESQUITE) FIBERS," vol. 8, no. 4, pp. 1384-1393, 2017.

31. S. Suresh and M. S. J. T. Charan, "STRENGTH AND BEHAVIOUR OF CONCRETE BY USING NATURAL AND ARTIFICIAL FIBRE COMBIATIONS," vol. 8, no. 4, pp. 1652-1658, 2017.

32. S. Ikkurthi and K. Kiran, "An experimental study on partial replacement of cement with bagasse ash in concrete mix," International Journal of Civil Engineering and Technology, vol. 8, pp. 452-455, 01/01 2015.

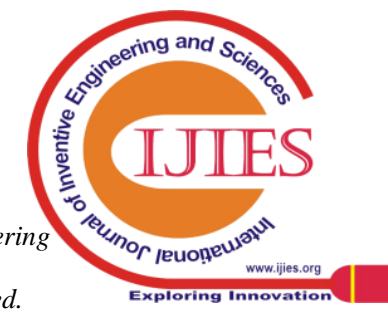




\section{A Review on Recent Advancements in Roller Compacted Concrete}

33. M. V. Bhargav, B. S. C. J. I. J. o. C. E. Kumar, and Technology, "Strength and Durability Study of Geopolymer Concrete Incorporating Metakaolin and Ggbs with 10m Alkali Activator Solution," vol. 8, no. 1, 2017.

34. M. Achyutha Kumar Reddy and R. R. Vummaneni, "Utilization of Bentonite in Concrete: A Review," 06/05 2019.

35. H. Rooholamini, A. Hassani, and M. R. M. Aliha, "Evaluating the effect of macro-synthetic fibre on the mechanical properties of roller-compacted concrete pavement using response surface methodology," Construction and Building Materials, vol. 159, pp. 517-529, 2018/01/20/ 2018.

36. M. K. Hygrive, I. S. Kishore, and K. J. I. J. o. C. E. Chari, "COMPARATIVE STUDY STRENGTH OF," vol. 8, no. 4, 2017.

37. V. V. K. Bhargava, K. B. Chari, and V. R. J. M. T. P. Rao, "Experimental investigation of M40 grade concrete with supplementary cementitious materials and glass fiber," 2020.

38. L. Ajay and A. K. Mangalampalli, "Experimental Study on Mechanical Properties of Concrete strengthened with Alkali Resistant Glass Fibers," Test Engineering and Management, vol. 83, pp. 16295-16298, 09/16 2020.

39. V. C. Khed, B. S. Mohammed, M. Liew, N. A. W. A. J. C. Zawawi, and B. Materials, "Development of response surface models for self-compacting hybrid fibre reinforced rubberized cementitious composite," vol. 232, p. 117191, 2020.

40. S. A. M. Rad and A. Modarres, "Durability properties of non-air entrained roller compacted concrete pavement containing coal waste ash in presence of de-icing salts," Cold Regions Science and Technology, vol. 137, pp. 48-59, 2017/05/01/ 2017.

41. S. Naveena and J. D. C. Kumar, "Experimental investigation on fibre reinforced beam column joint by partial replacement of cement with GGBS," in International Conference on Advances in Civil Engineering (ICACE-2019), 2019, vol. 21, p. 23.

42. A. Muralidhar and J. D. C. Kumar, "Strength and Durability Studies on Lightweight Fiber Reinforced Concrete by Incorporating with Palm Oil Shells," in International Conference on Advances in Civil Engineering (ICACE-2019), 2019, vol. 21, p. 23.

43. M. N.-T. Lam, D.-H. Le, and S. Jaritngam, "Compressive strength and durability properties of roller-compacted concrete pavement containing electric arc furnace slag aggregate and fly ash," Construction and Building Materials, vol. 191, pp. 912-922, 2018/12/10/ 2018

44. S. Saluja, K. Kaur, S. Goyal, and B. Bhattacharjee, "Assessing the effect of GGBS content and aggregate characteristics on drying shrinkage of roller compacted concrete," Construction and Building Materials, vol. 201, pp. 72-80, 2019/03/20/ 2019.

45. W. Zhang, S. Gong, and J. Zhang, "Effect of rubber particles and steel fibers on frost resistance of roller compacted concrete in potassium acetate solution," Construction and Building Materials, vol. 187, pp. 752-759, 2018/10/30/ 2018.

\section{AUTHORS PROFILE}

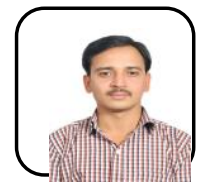

Dr. Veerendrakumar $\mathbf{C}$ Khed is an Associate professor in the Department of Civil Engineering, Koneru Lakshmaiah Education Foundation, Vaddeswaram, Guntur District - 522502, Andhra Pradesh, India. He earned Bachelor's degree in civil engineering in 2008 and M Tech degree in Structural Engineering in 2011 from PDA college of Engineering Kalaburagi. He was received $\mathrm{PhD}$ degree from University Technology Petronas (UTP), Malaysia in March 2019. He has 5 years of industrial experience as Structural Design Engineer. He has published 4 SCI articles and 12 Scopus Indexed articles in the field of Structural Engineering at various International Journals and conferences

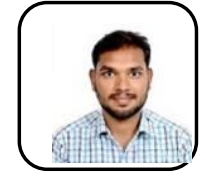

Mr. Gokulanadh V is a student of Master of Technology in Structural Engineering from Department of Civil Engineering, Koneru Lakshmaiah Education Foundation, Vaddeswaram, Guntur District - 522502, Andhra Pradesh, India. He has completed Bachelor of Engineering in Civil Engineering from Sathyabama Institute of Science and technology, Chennai, Tamil Nadu, India in 2018. His research interests include Steel structures Road bridges and Modern Concrete Materials.

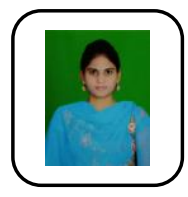

Miss. Hema Latha $\mathbf{M}$ is a student of Master of Technology in Structural Engineering from Department of Civil Engineering, Koneru Lakshmaiah Education Foundation, Vaddeswaram, Guntur District - 522502, Andhra Pradesh, India. She has completed Bachelor of Engineering in Civil Engineering from Dhanekula Institute of Engineering

and technology, Vijayawada, Andhra Pradesh, India in 2019. Her research interests include Bitumen study in Road Pavements and Modren and special Concrete Materials. 